Both Plomin and Hsu are passionate enough to take a shot, although their goals differ. Hsu is focused on the genetic basis of extreme intelligence. "My primary interest is why Einstein or Hawking is different from a normal person," he says. Plomin is sequencing high-performers as a way of homing in on genes that affect intelligence in the broader population. If enough of these are discovered, he thinks that it may be possible to predict someone's intelligence from an early age, and to offer help to children who are at risk of learning disabilities.

Publicity around the project has spawned some extreme reactions. An article published in March entitled 'China is Engineering Genius Babies' in the US arts and culture magazine VICE branded the study "a state-endorsed genetic-engineering project" that will allow parents to predict the IQs of embryos and selectively breed eversmarter children. ("That's nuts," says Hsu.) "Intelligence does push a lot of buttons. It's like waving a red flag to a bull," says Plomin. $\mathrm{He}$ argues that there is nothing wrong with using genetic information as the basis of educational interventions. "I'm interested in predicting learning problems early rather than waiting until kids get to school and then fail," he says.

But Paul Martin, a sociologist at the University of Sheffield, UK, is surprised that geneticists are still pursuing this line of research. "I think most people would say that's the wrong paradigm, when most educational research suggests that social factors are incredibly important," he says. "Strategically, this seems like something of a throwback."

More controversy is likely to flare when or if an intelligence factor emerges from the project. BGI is halfway through its sequencing, but it is unclear when findings will be released. "You might not see anything for a year," says Hsu; it depends on how long the analysis takes. In the meantime, as the cost of sequencing continues to fall, larger sample sizes may soon become available for studies of this kind. "In 2009, we thought it'd be impossible to have a schizophrenia study with 20,000 cases," says Peter Visscher, a geneticist from the University of Queensland in Brisbane, Australia. "Now, the international community is up to 40,000 ."

Still, he adds that the idea of predicting intelligence from a DNA sample is fanciful. "Even for human height, where you have samples of hundreds of thousands, the prediction you'd get for a newborn person isn't very accurate," he says. "That will be true for IQ for a long time to come." -

1. Deary, I. J., Johnson, W. \& Houlihan, L. M. Hum. Genet. 126, 215-232 (2009)

2. Chabris, C. F. et al. Psychol. Sci. 23, 1314-1323 (2012).

3. Davis, O. S. et al. Behav. Genet. 40, 759-767 (2010).

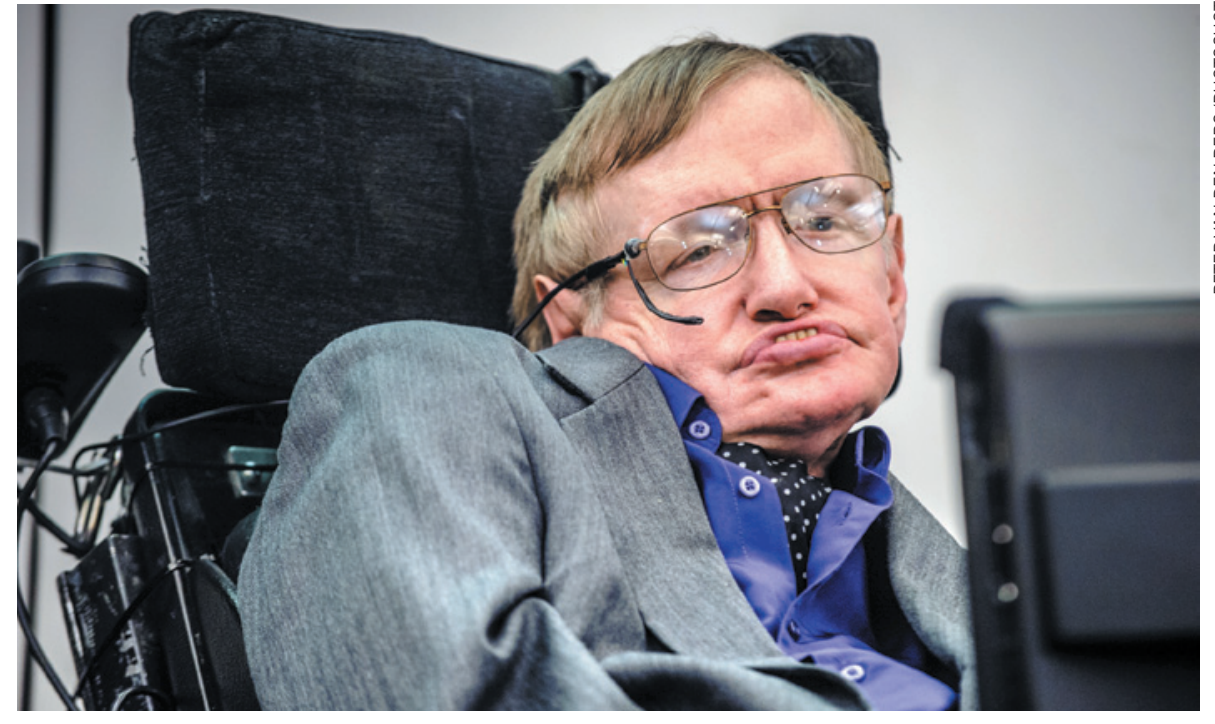

Stephen Hawking joins a list of scientists who have boycotted Israeli institutions and events.

\title{
ACADEMIC BOYCOTTS
}

\section{Hawking decision fuels Israel debate}

\section{Physicist's stance a 'turning point', claim supporters.}

\section{BY DANIEL CRESSEY}

A decision by one of the world's most famous physicists to withdraw from a conference due to be held in Israel next month has rekindled fierce debate in the United Kingdom over academic boycotts that are intended to protest against Israel's actions in the occupied Palestinian territories.

The decision, by Stephen Hawking of the University of Cambridge, UK, comes hot on the heels of an official ruling against a UK academic who had argued that, in part by repeatedly discussing a boycott of Israel, his trade union had created a hostile and anti-Semitic environment. Observers expect that the ruling will add fuel to this contentious fight.

Hawking, director of research at the Centre for Theoretical Cosmology, was scheduled to attend the Israeli Presidential Conference in Jerusalem, an event run in partnership with the Hebrew University of Jerusalem that will also celebrate the 90th birthday of Israeli President Shimon Peres. The gathering on 18-20 June will feature talks by scientists, other academics, artists and politicians on topics ranging from education and new media to political leadership.

Hawking wrote to the conference organizers on 3 May to say that he would not be attending so as to "respect the boycott" that some researchers have called for over the past decade. His decision was announced last week on the website of the British Committee for the Universities of Palestine, a London-based group calling for academics to cut links to Israeli institutions, and triggered intense media attention.

The University of Cambridge initially said in a statement released last Wednesday that the physicist, who has the debilitating neurological condition motor-neuron disease, was withdrawing for health reasons. Later that day, it said that it had been mistaken and that Hawking's decision was "based on advice from Palestinian academics that he should respect the boycott".

Conference organizer Israel Maimon, a lawyer, thinks that Hawking's decision was wrong, and says that attempts to create an academic boycott of Israel are "outrageous and improper".

Such efforts stretch back a decade in Britain. In 2002, more than 100 academics signed a letter published in The Guardian newspaper calling for a moratorium on European funding of, and contracts with, Israeli institutions, in protest at the "violent repression against the Palestinian people in the occupied territories". Since then, various campaign groups and trade unions of teachers and lecturers have proposed boycott motions at their meetings, some of which have been approved.

Steven Rose, an emeritus professor of 
- biology at the Open University in Milton Keynes, UK, organized the 2002 moratorium call with his wife Hilary Rose, a sociologist and emeritus professor at the University of Bradford. He claims that in the past ten years the campaign has "gone on expanding". Although there are no solid data on its effects, he says that moves by the Israeli government to counter it - such as 2011 legislation that outlaws boycott calls within Israel — are telling. "That shows it's having an impact," he says.

Other researchers question whether science in Israel has been significantly affected. The country collaborates with many institutions in Europe and the United States, and even with some academics in the occupied Palestinian territories. "I personally have not suffered from any boycott activity. I have relationships and collaborations with British scientists and scientists all over the world," says Ruth Arnon, an immunologist at the Weizmann Institute of Science in Rehovot, Israel, and president of the Israel Academy of Sciences and Humanities in Jerusalem, who has strongly criticized Hawking's decision and the boycott movement. "There may have been some who have been affected, but I don't know of any real effect."

Hawking's announcement is a "huge development" that may aid the boycott campaign in the United States, where it has traditionally not had much traction, says Jess Ghannam, a clinical psychiatrist at the University of California, San Francisco, and a member of the organizing committee of the US Campaign for the Academic and Cultural Boycott of Israel. "This is a real turn"There may
have been some
who have been
affected, but I
don't know of
any real effect." ing point, in terms of bringing attention to this issue."

Supporters of a boycott draw parallels between their movement and the campaigns for an aca-

demic boycott of South Africa that occurred during that country's apartheid regime. But critics say that Israel is being unfairly singled out, arguing that institutions and conferences in other nations with questionable humanrights records are not being boycotted. Some say that the focus on Israel is rooted in antiSemitism, a charge that Rose and others strongly deny.

In another recent event, a UK employment tribunal ruled on 22 March in favour of the University and College Union (UCU), a trade union for higher-education teachers, in a case brought against it in 2011. Ronnie Fraser, a mathematics teacher and a UCU member, had alleged "institutional anti-Semitism" that was in part due to repeated votes at the union's annual meetings to boycott Israeli academic institutions. Although the union concluded in 2007 , on the basis of legal advice, that a boycott would be unlawful, votes at subsequent meetings have approved related motions, such as discussing Palestinian calls for a boycott.

The tribunal dismissed Fraser's complaint, calling it "an impermissible attempt to achieve a political end by litigious means". Some academics fear that this could embolden the boycott movement. David Hirsh, a sociologist who researches anti-Semitism at Goldsmiths, University of London, and who helped to spearhead Britain's anti-boycott Engage campaign, says that it gives a judicial stamp to the idea that such a boycott is not anti-Semitic. "That's really damaging," he says.

Meanwhile, Richard Axel, a neuroscientist at Columbia University in New York, says that he will go ahead with plans to attend the Jerusalem meeting next month. "I do have serious concerns over the Israeli occupation of Palestinian territories. I'm deeply troubled by it," he says. "But I do not feel an academic boycott of Israeli universities will in any significant way make progress to a resolution of that crisis." -

\section{Meeting targets lab lapses}

\section{Attendees search for ways to tackle misconduct and sloppy science.}

\section{BY RICHARD VAN NOORDEN}

$\mathrm{E}$ very conference has its own brand of comedy, and the humour is deliciously dark when the subject is misconduct. James Kroll, who investigates misconduct allegations at the US National Science Foundation, knew he would get a laugh with his classic "excuses for plagiarism" slide, which included one scientist who blamed acid reflux, and another who was "distracted by bird vocalizations".

But any 'would-you-believe-that?' jocularity at the 3rd World Conference on Research Integrity, held last week in Montreal, Canada, was light relief from the serious concerns that attendees had come to tackle. Allegations of misconduct are rising, retractions are on the up and concern is growing that sloppy lab practices are leading to unreliable research.

Experts debate whether the trends represent real increases or simply growing awareness. But attendees at the meeting were brimming with plans to combat problems ranging from out-and-out fraud to selective publication of experiments. Among the potential solutions are spot audits of research data; independent replication of results; requirements for data-sharing; ethics codes and training; forced accountability for institutions; and greater protection for whistle-blowers. Still, the attendees acknowledged that it is hard to measure whether these strategies work - and hardest of all to provide incentives for change in a system in which scientists are rewarded for speedy success.

"We know that research misconduct is more common than expected," Nicholas Steneck, an ethicist at the University of Michigan in Ann Arbor, told the meeting of more than 360 attendees from 45 countries, "but we don't know if it is getting any worse and whether it can be prevented or deterred."

In recent years, the number of misconductrelated inquiries has spiked at national oversight and advisory bodies (see 'Questions of integrity'), and at research journals. Veronique Kiermer, executive editor of Nature Publishing
D NATURE.COM See Nature's special on reproducible research: go.nature.com/huhbyr
Group in New York, says that anonymous allegations are growing, "taking a toll" on editors who must investigate them, although many turn out to be ill-founded.

Lots of journals already scan manuscripts with plagiarism software. Bernd Pulverer, chief editor of The EMBO Journal, said at the meeting that his publication began systematic pre-publication examination of images in papers last November; around $4 \%$ contain "serious manipulations", he said. But more discoveries do not mean that more misconduct is occurring. The Journal of Cell Biology has consistently revoked about $1 \%$ of accepted publications for image manipulation over the past decade, with no upward trend.

Meta-analyses suggest ${ }^{1}$ that $1-2 \%$ of scientists admit to misconduct in anonymous surveys. A similar proportion admit to plagiarism, and $31 \%$ say that they have witnessed plagiarism by others, according to unpublished work by Daniele Fanelli, who studies science policy and misconduct at the University of Edinburgh, UK. "The field needs quantitative research - otherwise, we are just talking 